\title{
4-1-2013
}

\section{International Law and the Future of Peace}

Diane Marie Amann

University of Georgia School of Law, amann@uga.edu

\section{Repository Citation}

Marie Amann, Diane, "International Law and the Future of Peace" (2013). Presentations and Speeches. 30. https://digitalcommons.law.uga.edu/fac_presp/30

This Article is brought to you for free and open access by the Faculty Scholarship at Digital Commons @ University of Georgia School of Law. It has been accepted for inclusion in Presentations and Speeches by an authorized administrator of Digital Commons @ University of Georgia School of Law. Please share how you have benefited from this access For more information, please contact tstriepe@uga.edu. 
INTERNATIONAL LAW AND THE FUTURE OF PEACE

Diane Marie Amann ${ }^{*}$

I am very honored, and most deeply humbled, by this Prominent Woman in International Law award. I am humbled when I look at the list of prior recipients. ${ }^{1}$ They include: Patricia Wald and Mireille Delmas-Marty, two women whose lifework has inspired my own; stateswomen like Patricia Schroeder and Geraldine Ferraro; American Society of International Law leaders like Lucy Reed and Edith Brown Weiss; another woman who serves as a Special Adviser to the International Criminal Court Prosecutor, Patricia Viseur Sellers; and even a woman who, like me, once clerked for Justice John Paul Stevens, Carol Lee. (Indeed, as of today Justice Stevens may add "feeder judge for PWIL award" to his long list of accomplishments.)

I am even more humbled when I think of all the amazing international law women who deserve this award. To name a very few: our new ASIL President-Elect, Lori Damrosch (who is here with her mother, Jean Fisler, a WILIG stalwart), not to mention ASIL fearless leader Betsy Andersen; Joan Donoghue and her sisters on the International Court of Justice; the ICC Prosecutor whom I am honored to serve, Fatou Bensouda, as well as my sister Special Advisers, Leila Sadat

\footnotetext{
* Emily and Ernest Woodruff Chair in International Law, University of Georgia School of Law. This talk was delivered on April 4, 2013, during the American Society of International Law Women in International Law Interest Group luncheon at which the author was honored with the group's Prominent Woman in International Law award. This essay is part of a larger project on the value of peace; that project has been aided by research assistance from Kaitlin M. Ball and Anders S. Nelson, by library assistance from T.J. Striepe, and by comments made during my presentations at the International Criminal Court and the International Criminal Tribunal for the former Yugoslavia, as well as the law schools at Arizona State University and the University of Georgia.

${ }^{1}$ See The American Society of International Law Women in International Law Interest Group Prominent Woman in International Law Award, available at https://file.smartbins.net/download/2afe25c4357c5eea4eeb62fe8f8edd12 (visited Mar. 31, 2013).
} 
and Brigid Inder; stateswomen like Mary Robinson and Hillary Clinton; and still another woman whose lifework has inspired my own, Martha Minow.

I am humbled, finally, to accept this award not only on my behalf, but also on behalf of my three co-editors, Kate Doty, Jaya Ramji-Nogales, and Beth Van Schaack, and, indeed, on behalf of the more than 300 women (plus a few men) who have contributed to IntLawGrrls. ${ }^{2}$ Those of you who are with us here today, please stand. Thank you. This award belongs to every one of you.

(You know, I never had a sister, and my mother has been gone for more than a decade now. But I would like to give shout-out to the men in my life: my husband, Peter O’Neill, and our son, Tiernan O'Neill. Tiernan is in school today, so they had to stay at home, but they are here today in my heart.)

Even though we are all winners, our general dislike for cacophony demands that only one of us speak today. That honor falls to me, and given that this is a lunch talk, I have chosen a light and modest topic. Well, no, I'm afraid I have not. My title is, in fact, "International Law and the Future of Peace." For this audience, it might more fittingly be called "Peace: A Feminist Project."3 As many of you know, IntLawGrrls often dedicated their contributions to transnational foremothers. ${ }^{4}$ Consistent with the assumption that we women are more nurturing than, shall we say, other humans, ${ }^{5}$ contributors frequently chose to honor pacifist heroines. Many from this

\footnotetext{
${ }^{2}$ For the roster of persons who contributed during the 2007-12 edition of this blog, see Contributors, INTLAwGRRLS, http://www.intlawgrrls.com/p/contributors.html (visited Mar. 31, 2013). Contributors to the current edition are listed as "Voices" in the righthand column at INTLAWGRRLS, http://ilg2.org/ (visited Mar. 31, 2013).

${ }^{3}$ Many articles point to a "feminist project" in law generally, and international law specifically - so much so that at a previous annual meeting of this Society, one panelist spoke of "the perennial question of "what is the feminist project in law?" Catherine O'Rourke, Remarks, in Feminism v. Feminism: What Is a Feminist Approach to Transnational Criminal Law?, 102 ASIL Proc. 269, 274, 275 (2008). The first journal reference to the term found in Westlaw is Catharine A. MacKinnon, Toward Feminist Jurisprudence, 34 STAN. L. REV. 703, 710 (1982) (reviewing ANN JonES, WOMEN WHO KILL (1980)).

${ }^{4}$ For the complete list of women honored, see Foremothers, INTLAWGRRLS, http://www.intlawgrrls.com/p/foremothers.html (visited Mar. 31, 2013).

${ }^{5}$ This assumption is, of course, contestable. See Hilary Charlesworth, Are Women Peaceful? Reflections on the Role
} 
group of foremothers rode what is sometimes called the first wave of feminism - that period in the late nineteenth and early twentieth centuries when many women (plus a few men) campaigned for change. Members of this movement are best known for winning women the vote; that goal, however, was but one of several that animated them. Equally important to many of these feminists was pacifism. Theirs was an all-out quest to end war. One such campaigner was Jeannette Rankin, who, as a rare woman member of Congress, voted "No" on legislation by which the United States entered into World War I and, twenty-three years later, into World War II. ${ }^{6}$ Another was Jane Addams, who lectured for peace and against war, and led the U.S.-based Women's Peace Party. In 1915, Addams chaired the International Congress of Women at The Hague and became the founding President of the Women's International League for Peace and Freedom, an organization that thrives to this day. For her efforts Addams eventually would receive the Nobel Peace Prize. ${ }^{7}$ Despite her achievements, it must be noted, ASIL denied Addams's application for membership: as chronicled in a 1974 American Journal of International Law article co-authored by Alona Evans, Addams was "invited, instead, to subscribe to the Journal 'for the same amount as the annual dues ...." ${ }^{\prime 8}$ No woman was admitted to membership until 1921, when the Constitution's guarantee of women's suffrage appears to have forced the Society's hand. ${ }^{9}$

It must also be noted that not every foremother was a woman of peace. Quite to the contrary. The pirate Gráinne Ní Mháille, or Grace O’Malley, was cited by me and by nearly every

of Women in Peace-Building, 16 FEM. LEG. STUD. 347, 357 (2008) (challenging "[t]he idea that women are somehow predisposed to be peaceful and naturally gifted as peace-builders").

6 See Norma Smith, Jeannette Rankin 16, 26, 105, 111-14,156, 183, 236 (2002).

7 All autobiographical details are drawn from Peace 1931: Jane Addams, Nicholas Murray Butler, in II NoBEL

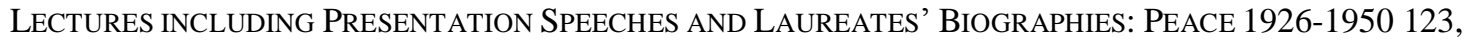
132-35(Frederick W. Haberman ed., 1972).

8 Alona E. Evans \& Carol Per Lee Plumb, Women and the American Society of International Law, 68 AM. J. INT'L L. 290, 291 (1974) (quoting letter from James Brown Scott, then ASIL's Recording Secretary and later its President, to “Miss Jane Adams,” April 17, 1915); see FredERIC L. KIRGIS, THE AMERICAN SOCIETY OF INTERNATIONAL LAW'S FIRST CENTURY 1906-2006 12 (2006) (recounting this history).

${ }^{9}$ See Evans \& Plumb, supra note 8, at 291; see also KIRGIS, supra note 8, at 12. 
other Irish IntLawGrrl. Selected from Asia were Lakshmi Bai and Trưng Trắc; from Africa, Ndaté Yàlla; and from the Caribbean, Anacaona and Nanny of the Maroons. At instances in her career, each of these women resorted to combat as a means to keep her people free from conquest or exploitation.

That we IntLawGrrls chose to honor warriors and pacifists alike points to a central paradox of peace. In its purest sense, pacifism connotes opposition to violence. ${ }^{10}$ And surely, the human condition is advanced every time that a life-threatening attack is averted. But the absence of that sort of violence - the nonuse of force, as we lawyers call it - is not, in and of itself, peace. Whenever a careful examination reveals an apparent absence of violence to be little more than a veneer that masks exploitation, there is no peace. It is in recognition of this fact that the peacemaker who died forty-five years ago today, Dr. Martin Luther King, Jr., made clear his preference not for "negative peace which is the absence of tension," but rather for "positive peace which is the presence of justice."11 Similarly, a leading theorist of peace, the Norwegian sociologist Johan Galtung, distinguished attacks, which he called "direct violence," from exploitation, which he called "structural violence." "2 Galtung insisted on attention to the latter as well as the former, "not only because exploitation may lead to direct violence," but also, and perhaps most importantly, because exploitation "is violence in itself."13 This fuller understanding of peace, this acknowledgment that exploitation is itself violence, poses a challenge, Galtung wrote: the challenge is to reduce direct violence - to promote the nonuse of force - without

\footnotetext{
${ }^{10}$ See Pacifism, in The American Herit age Dictionary of the English Language 941 (William Morris ed., 1973) (listing, as the second meaning of the term, "[o]pposition to war or violence as a means of resolving disputes," and, as the first meaning, "belief that disputes between nations should and can be settled peacefully").

${ }^{11}$ MARTin LuTHER King, JR., LeTter FrOM THE BiRMinghAM JAIL 15-16 (HarperSan Francisco 1994) (1963).

12 Johan Galtung, Nonterritorial Actors and the Problem of Peace, in ON THE CREATION OF A JUST WORLD ORDER 151, 151 (Saul H. Mendlovitz ed., 1975).

${ }^{13} I d$. at 154 (emphasis in original omitted).
} 
simultaneously enabling exploitation. ${ }^{14}$ In short, there is a line to be drawn, and in our world, the task of drawing that line often falls to the shapers of international law.

We all know in broad outline the rules that govern the use of force. They appear in the foundational text of modern international law, the Charter of the United Nations. From 1945 onwards, U.N. member states promised to "settle their disputes by peaceful means in such a manner that international peace and security, and justice, are not endangered," and further to "refrain in their international relations from the threat or use of force against the territorial integrity or political independence of any state ...." States reserved an "inherent right" of self-defense, but only "if an armed attack occurs ..., until the Security Council has taken measures necessary to maintain international peace and security." ${ }^{16}$ We know too that at Nuremberg and in Tokyo, convicted leaders were hanged for committing aggressive war - called crimes against peace - and for the atrocities that ensued. ${ }^{17}$ Taken together, these developments signaled that no state would be permitted to launch an offensive attack, that none therefore would need to exercise self-defense, and that leaders who acted in violation would be punished. That legal framework ought to have put an end to war, or at least to war between states. It did not.

The next six decades saw a number of international armed conflicts, as well as many conflicts dubbed "not of an international character" even though outside countries were aiding one

${ }^{14}$ Using the term "associative policies" to refer to interstate efforts at cooperation, Galtung wrote:

Clearly the problem is to bring parties together to prevent direct violence without at the same time creating structural violence. This is the general problem of peace politics in our time: how to practice associative policies as a bulwark against direct violence without at the same time getting

Id. into the pitfalls of structural violence.

${ }^{15}$ U.N. CHARTER, art. 2(3), (4).

${ }^{16} I d$., art. 51.

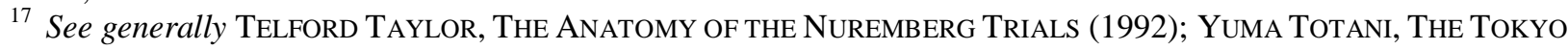
WAr Crimes Trial (2008). $C f$. James F. Willis, Prologue to NuremberG 80, 174-75 (1982) (stating that U.S. prosecutors at Nuremberg argued that aggression "had become a customary, uncodified war crime by virtue of a progressive chain of events," dating to the post-World War I era and including "the adoption of the Kellogg-Briand treaty outlawing war"). 
side or another. Examples are the Iran-Iraq War and the struggle in the Democratic Republic of the Congo, each of which claimed a million or more lives. ${ }^{18}$ In the face of such conflicts, the Security Council often failed to shoulder its responsibility to maintain peace; that is, it failed both to stop attacks and to bring attackers to account. ${ }^{19}$ From these failures emerged new doctrines, by which states sought to justify acting outside the confines of the Council. The timing requirement for self-defense was said to permit reaction not only after, or in immediate anticipation of, an armed attack, but also well before a presumed attack is imminent. ${ }^{20}$ States were said to be free to use force so long as such use would not be "inconsistent with the Purposes of the United Nations"; ${ }^{21}$ for example, in order to rescue their own nationals. ${ }^{22}$ Also said to serve U.N. purposes was the resort to force in defense of others, commonly known, of course, as humanitarian intervention. ${ }^{23}$ And what of the crime against peace that was prosecuted in the Nuremberg era? Concern was expressed; it was said that authorizing the ICC to punish this offense of aggression might have a chilling effect on interventions undertaken in the name of rescuing humanity. ${ }^{24}$ Among those

\footnotetext{
${ }^{18}$ See Ian Black, Iran and Iraq remember war that cost more than a million lives, GUARDIAN (London), Sept. 23, 2010, http://www.guardian.co.uk/world/2010/sep/23/iran-iraq-war-anniversary; Peter James Spielmann, Review of Congo war halves death toll, AP DATASTREAM, Jan. 20, 2010, available in Westlaw, 1/20/10 AP DataStream 19:07:01 (reporting on studies that lowered original casualty estimate of 5.4 million to half that number, still well over 2 million persons).

${ }^{19}$ See U.N. CHARTER, art. 24(1) ("In order to ensure prompt and effective action by the United Nations, its Members confer on the Security Council primary responsibility for the maintenance of international peace and security, and agree that in carrying out its duties under this responsibility the Security Council acts on their behalf.").

${ }^{20}$ See e. e.g., The NATIONAL SeCURity STRATEgY OF THE United STATES OF AMERICA (Sept. 2002), available at http://georgewbush-whitehouse.archives.gov/nsc/nss/2002/, discussed generally in Diane Marie Amann, Unipolar Disorder: A European Perspective on U.S. Security Strategy, 27 HASTINGS InT'L \& CoMP. L. REV. 447 (2004).

${ }^{21}$ U.N. CHARTER, art. 2(3).

${ }^{22}$ See generally Kristen E. Eichensehr, Note, Defending Nationals Abroad: Assessing the Lawfulness of Forcible Hostage Rescues, 48 VA. J. INT'L L. 451 (2008).

${ }^{23}$ See generally Saira Mohamed, Restructuring the Debate on Unauthorized Humanitarian Intervention, 88 N.C. L. Rev. 1275 (2010). Cf. Diane Marie Amann, The Course of True Human Rights Progress Never Did Run Smooth, 21 HARV. H. RTS. J. 171, 173-74 \& n.11 (2008) [hereinafter Amann, Course] (writing of some commentators' uneasiness respecting humanitarian intervention).

${ }^{24}$ See, e.g., Erin Creegan, A Permanent Hybrid Court for Terrorism, 26 AM. U. INT'L L. REv. 237, 254-55 (2011); Beth Van Schaack, "The Grass That Gets Trampled When Elephants Fight": Will the Codification of the Crime of Aggression Protect Women?,15 UCLA J. INT'L L. \& ForeIGN AFF. 327, 334 (2010). But see Stefan Barriga and Leena Grover, a Historic Breakthrough on the Crime of Aggression, 105 AM. J. INT'L L. 517, 522 n.14 (2011) (“A genuine
} 
giving voice to this concern was my dear colleague, Professor Van Schaack. While putting it forward in a 2010 article, however, she acknowledged that privileging this concern has consequences. To deny international mechanisms the power to question war-making decisions is, in effect, to give leaders the right to choose whether to intervene. Accepting that result "requires," she wrote, "coming to terms with a certain valorization of militarism." 25

Her words serve to underscore one feature of these emergent doctrines: they condone violence; that is, they justify meeting violence with violence. In my view, this too is cause for concern. Suffering and death, even atrocities, are the inevitable spawn even of just wars. ${ }^{26}$ Doctrinal emphasis on forcible options tends to downplay human $\operatorname{costs}^{27}$ and to inflate presumed threats; this may be discerned in speeches in which officials of the United States have sought to defend lethal drone strikes. ${ }^{28}$ An emphasis on force likewise tends to disregard nonforcible paths

humanitarian intervention without Security Council authorization would, by its gravity and character, not fulfill the criterion of a manifest Charter violation since its legality under general international law is at least debatable.") (citing Claus Kreß, Time for Decision: Some Thoughts on the Immediate Future of the Crime of Aggression: A Reply to Andreas Paulus, 20 EuR. J. INT'L L. 1129 (2010)).

${ }^{25}$ Van Schaack, supra note 24, at 334.

${ }^{26}$ See Diane Marie Amann, Kampala as cause to celebrate, InTLAWGRRLS, Sept. 10, 2010, http://www.intlawgrrls.com/2010/09/kampala-as-cause-to-celebrate.html (quoting lecture in which Professor William A. Schabas accepted that at times force may be necessary, but added that he would not "exaggerate the importance of that, because war brings atrocities, inevitably"').

${ }^{27}$ At the time of the first Gulf War, one commentator called "disturbing" the fact that, in contrast with environmental damage, the issue of civilian casualties had "attracted almost no scholarly analysis. Judith Gail Gardam, The Law of Armed Conflict: A Gendered Regime?, in ReCONCEIVING REALITY: WOMEN AND INTERNATIONAL LAW 171, 172 (Dorinda G. Dallmeyer ed., 1993). Notwithstanding observation of "the salience of civilians in modern conflicts," Adam Roberts, The Civilian in Modern War, 12 Y.B. InT'L HuMANITARIAN L. 13, 16 (2009), quantification of the losses suffered by civilians remains less accurate than the quantification of military casualties. See Diane Marie Amann, ... and counting..., INTLAWGRRLS, Feb. 24, 2007 (noting variations in casualty counts in Iraq, and quoting an Associated Press report of a comment by a Duke University political scientist, that "[p]eople in democracies generally don't shy away from inflicting civilian casualties"), http://www.intlawgrrls.com/2007/02/and-counting.html.

${ }^{28}$ See John O. Brennan, The Ethics and Efficacy of the President's Counterterrorism Strategy (Apr. 30, 2012) (stating in speech that "[a]s a matter of international law, the United States is in an armed conflict with al-Qa'ida, the Taliban, and associated forces, in response to the 9/11 attacks, and we may also use force consistent with our inherent right of national self-defense," and furthermore that " $[\mathrm{t}]$ here is nothing in international law that bans the use of remotely piloted aircraft for this purpose or that prohibits us from using lethal force against our enemies outside of an active battlefield, at least when the country involved consents or is unable or unwilling to take action against the threat"), available at http://www.cfr.org/counterterrorism/brennans-speech-counterterrorism-april-2012/p28100; Harold Hongju Koh, The Obama Administration and International Law (Mar. 25, 2010) (asserting, in an ASIL annual 
to peace; this is evident in writings that consider the concept of responsibility to protect almost solely within the context of military intervention. ${ }^{29}$ In similar vein, the easy justification of force invites states to abandon too hastily the difficult pursuit of pacific dispute settlement. The example that jumps to mind is the 2003 decision to dispense with diplomacy and invade Iraq. Invasion led not to the promised discovery of enemy weapons of mass destruction, but rather to the deaths of nearly 5,000 service members and more than 100,000 civilians, to the displacement of well over a million persons, and to costs in the trillions of dollars. ${ }^{30}$

Our pacifist heroine, Jane Addams, would have had none of this. In 1915, a year into the conflict on the Continent, Addams bemoaned that "because of war, the finest consciences in Europe are put to the old business of self-justification, of utilizing outgrown myths to explain the course of action which their governments have taken." ${ }^{31}$ Addams argued that the war footing

meeting speech, that "a state that is engaged in an armed conflict or in legitimate self-defense is not required to provide targets with legal process before the state may use lethal force"),

http://www.state.gov/s/1/releases/remarks/139119.htm; U.S. Dep't of Justice, Attorney General Eric Holder Speaks at Northwestern University School of Law (Mar. 5, 2012) (contending that "the fact that we are not in a conventional war" changes neither the domestic authority "to protect the nation from any imminent threat of violent attack" nor the international law that "recognizes the inherent right of national self-defense"),

http://www.justice.gov/iso/opa/ag/speeches/2012/ag-speech-1203051.html.

${ }_{29}$ See, e.g., Sara McLaughlin Mitchell \& Paul F. Diehl, Caution in What You Wish For: the Consequences of a Right to Democracy, 48 StAn. J. InT'L L. 289, 295 (2012); Bart M.J. Szewczyk, Variable Multipolarity and U.N. Security Council Reform, 53 HARV. InT'L L.J. 449, 478, $492-93$ (2012); Rosa Brooks, The problem with the drone war that no one's talking about, DALLAS MORNING NEWs, Feb. 22, 2013,

http://www.dallasnews.com/opinion/sunday-commentary/20130222-rosa-brooks-the-problem-with-the-drone-war-th at-no-ones-talking-about.ece. For a more comprehensive account of the doctrine, see Patricia O'Brien, The United Nations \& the Responsibility to Protect, INTLAWGRRLS, Apr. 5, 2012 (reprinting U.N. Legal Counsel's remarks at ASIL's 2010 annual meeting), http://www.intlawgrrls.com/2012/04/united-nations-responsibility-to.html.

${ }^{30}$ See Iraq Body Count, http://www.iraqbodycount.org/ (visited Mar. 31, 2013) (stating that there had been between 111,840 and 122,320 "civilian deaths from violence" since the Iraq invasion); Iraq Casualty Count,

http://icasualties.org/ (visited Mar. 31, 2013) (tabulating 4,804 deaths of coalition service members between 2003 and 2012); Ernesto Londoño, Iraq, Afghan wars will cost to $\$ 4$ trillion to $\$ 6$ trillion, Harvard study says, WASH. PosT, Mar. 28, 2013, 2013 WLNR 7696661; Studies examine effects of Iraq war on US and UK, DEUTSCHE-WeLLE, Mar. 15, 2013 (citing nearly 200,000 deaths and costs of more than $\$ 2$ trillion), http://www.dw.de/studies-examine-effects-of-iraq-war-on-us-and-uk/a-16676385; U.N. High Comm'r for Refugees, 2013 UNHCR country operations profile - Iraq, http://www.unhcr.org/pages/49e486426.html (visited Mar. 31, 2013) (citing, in table, more than 1.4 million Iraqi refugees and another 1.3 million internally displaced Iraqis).

${ }^{31}$ Jane Addams, What War Is Destroying, in 4 JANE ADDAMS's WRITINGS ON PEACE 61, 61 (Marilyn Fischer \& Judy D. Whipps eds., 2003) [hereinafter WRITINGS ON PEACE] (reprinting essay originally published at volume 77 of THE 
dispossessed women in particular of values in which they "held a vested interest"; the ideal of a state founded upon individual liberty rather than collective fear, for example, as well as "the belief that human life is sacred above all else that the planet contains." 32

"Yes, well, but," I hear some of you thinking. "But what happens when human life is not held sacred? What happens when a president so values power, or a rebel so lusts for power, that he will harm even his own people in order to secure it?" In sum, you ask: "What is to be done about Syria?"

In contrast with Libya, where NATO’s 2011 actions are said to have prevented a bloodbath, ${ }^{33}$ in Syria, the past two years of nonaction have produced a death toll that exceeds 70,000 children, women, and men. ${ }^{34}$ Countless more Syrians have suffered displacement, rape, or torture. Syria seems a paradigmatic case for military intervention. Yet it must be remembered that other means have not really been tried. The ultimate international cause of the Syrian tragedy is a failure of diplomacy; that is, the refusal of an essential U.N. member state to exert genuine, effective pressure on the Syrian regime. ${ }^{35}$ Russia's refusal has impeded attempts to ease the crisis via nonforcible measures, such as the sanctions and the ICC referral that preceded NATO's action

Advocate of Peace, Mar. 1915, at 64-65).

${ }^{32}$ See id. at 61-62. I draw the term "collective fear" from Addams's references to "a trial conception" of "patriotism" as a call to "march and fight" in order to "save their homes from destruction." Id. at 61. It was, she wrote, "an irrational appeal which ought to have left the world long since." Id.

33 See Helene Cooper \& Steven Lee Myers, Shift by Clinton Helped Persuade President to Take a Harder Line, N.Y. TIMES, Mar. 19, 2011, at A1 (discussing how desire to prevent a repeat of the 1994 Rwanda genocide motivated U.S. officials to push for military intervention in Libya).

${ }^{34}$ See Statement by the High Commissioner for Human Rights to the Security Council, on 12 February 2013 during the Council's thematic debate on the Protection of Civilians, http://www.ohchr.org/EN/NewsEvents/Pages/DisplayNews.aspx?NewsID=12990\&LangID=E (visited Mar. 31, 2013); Raja Abdulrahim, Syrian civil war enters third year, L.A. TIMES, Mar. 15, 2013, http://www.latimes.com/news/world/worldnow/la-fg-wn-syria-war-assad-third-year-20130315,0,1650959.story. 35 See Samuel Charap, Why Russia Won't Help on Syria, N.Y. TIMES, Jan. 2, 2013, 2013 WLNR 76564 ("Moscow does not believe the U.N. Security Council should be in the business of endorsing the removal of a sitting government."); Denis Corboy, William Courtney \& Kenneth Yalowitz, Dealing With Two Russias, N.Y. TimES, Jan. 25, 2013, 2013 WLNR 1940921 (writing that "stubborn support for the Assad regime in Syria has tarnished the prestige of Russia"). Russia's support is essential because, as a permanent member of the Security Council, it may veto any Council action with which it disagrees. See U.N. CHARTER, arts. 23(1), 27(3). 
in Libya. ${ }^{36}$ Russia's refusal, moreover, has permitted unconscionable loss of life and stoked calls for military intervention without the approval of the Security Council.

Let us suppose for a moment that the calls for freedom-fighting prevail, that a coalition of states deploys armed force against the Syrian regime. Is there then is a role for persons who prefer pacific settlement of disputes? There is, I would submit, and it is a role with at least three facets. The first facet is to pinpoint the lines drawn by international law - to caution that a decision to operate in the doctrinal grey area of humanitarian intervention does not free policymakers from other laws of armed conflict, such as the principle of proportionality and the injunction to wage war as humanely as possible. The second facet is to remind that even well-intended violence begets violence - providing a case in point is the report that weapons looted during the chaos in Libya two years ago today fuel the combat in Mali. ${ }^{37}$ Finally, the third facet is to continue the hard work of improving global society - to demand not only that each state lives up to its own obligations, but also that each state pressures others to follow suit and sanctions them when they fail to do so.

This demand helps to ensure human security. ${ }^{38}$ This demand seeks not just to stop attacks, but also to undo exploitation; that is, to buttress the legal framework that protects humans against

\footnotetext{
36 See S.C. Res. 1970, UN. Doc. S/RES/1970 (Feb. 26, 2011).

37 See C. J. Chivers, Looted Libyan Arms in Mali May Have Shifted Conflict's Path, N.Y. TiMES, Feb. 8, 2013 , at A4. Libya itself reportedly has remained unstable. See Steven Erlanger, Two Years After Revolt, Libya Faces a Host of Problems, N.Y. TIMES, Feb.13, 2013, at A7.

${ }^{38}$ I choose to write of human "security," rather than "rights," for the reason that rights too often are realized only after they are violated, and even then only by the few victims who possess resources to seek redress. I have written elsewhere:
}

[W]hereas 'human rights' activists often look to judges for vindication, in the form of post hoc compensation for individual deprivations of rights, 'human security' is not so limited. Security may be secured without resort to the courts - indeed, I would argue that it is best secured when it is embedded in the structure of the system, so that insecurity never occurs. In this sense the actors most responsible for human security are the legislators who establish the protective/preventive structure and the executive officers who implement that structure. Judges are not the first guarantors of 
and within the state. In short, this demand subverts structural violence as well as direct violence, and so serves the fullest understanding of peace.

Not surprisingly, this is a demand that Jane Addams made upon the United States when it joined World War I. With an eye to postwar reconstruction, she wrote that the United States must "protec $[\mathrm{t}]$ and preserv[e] the higher standards of internationalism." ${ }^{39}$ And casting her eye at the war itself, she urged the United States to send Europe food, so that not even the enemy's "women and children" would starve. ${ }^{40}$ Addams's emphasis on children was no accident. Like many feminists of her era, as dear to her as suffrage and pacifism were children; to be precise, the freeing of children from factory labor and the protecting of children from the worst ravages of war.

This last goal, of seeking peace for future generations, inspires me in my new role as Special Adviser on Children in and affected by Armed Conflict. It provides me with one answer to the perennial question, "What can I do?" With your indulgence, before closing this talk I would like to suggest a few more things that we can do.

Let me first address what we can do as members of ASIL's Women in International Law

\section{Interest Group.}

We can honor our foremothers. We can read and teach and write about women such as

Addams, like me a native Illinoisan, and Congresswoman Rankin, who for years lived just miles

from what is now my home in north Georgia. We can ask ASIL to right wrongs done a century ago

human security; they are, rather, the very last resort. In a system that fully guaranteed human security, the judiciary would have no role at all to play.

Diane Marie Amann, Climate Change and Human Security, at 3 (English-language version, available at https://www.dropbox.com/s/rycj0o0e5da6iee/climate_eng_2008.pdf, of Diane Marie Amann, Le changement climatique et la sécurité humaine, in REGARDS CROISÉS SUR L'INTERNATIONALISATION DU DROIT :

FRANCE-ÉTATS-UnIS 239, 242-43 (Mireille Delmas-Marty \& Stephen Breyer, eds., 2009)). See also Amann, Course, supra note 23, at 176-79 (exploring the concept of human security within the framework of U.S. understandings of the role of the state vis-à-vis individual persons).

39 Jane Addams, Patriotism and Pacifists in War Time, in Writings on PeACE, supra note 31, at 153, 159, 160 (reprinting presentation made at May 15, 1917, meeting of the City Club of Chicago).

${ }^{40} I d$. 
by granting posthumous membership to all women whose pre-1921 applications were denied.

Alona Evans's article cites not only Addams in this regard, but also Belva Ann Lockwood, who was the first woman to run for President of the United States and the first to argue a case before the Supreme Court. ${ }^{41}$

We can also honor Evans, whose Wellesley career included a stint as thesis advisor to Hillary Rodham, the young woman who grew to become our most recent Secretary of State. ${ }^{42}$ Evans's long service to ASIL was recognized by her election as its first woman President, in 1980 - but then cut short when she died before the year was out. ${ }^{43}$ In her will Evans left $\$ 40,000$ to the Society ${ }^{44}$ it is my personal hope that one day she will be made the namesake of ASIL's Patron-level donors.

Let me conclude by reciting what we can do as scholars and practitioners of international law.

We can work to assure that nonforcible means of intervention are fully considered. And we can insist that when such mechanisms - for instance, Security Council referral to the ICC - are chosen, those mechanisms are given the monetary and other resources they need to complete the task before them.

We can expose to searching scrutiny, against the backdrop of law, every use of armed force. And even when what they have to say causes some of us discomfort, we can welcome, and not shun, the voices of our sisters, and brothers, who speak law to power.

\footnotetext{
${ }^{41}$ See Evans \& Plumb, supra note 8, at 290-91; see also KIRGIS, supra note 7, at 12.

42 See Hillary D. Rodham, "There Is Only the Fight..." An Analysis of the Alinsky Model i (1969) (unpublished B.A. thesis, Wellesley University) (on file with the Wellesley University Library) (expressing "special appreciation" to "Miss Alona E. Evans for her thoughtful questioning and careful editing that clarified fuzzy thinking and tortured prose").

${ }^{43}$ See KIRGIS, supra note 8, at 391-92.

${ }^{44}$ See id. at 392 n.66.
} 
In these and other ways, we, each of us, can aid the pursuit of peace. 